Génét. Sél. Evol., 1983, 15 (2), 257-262

\title{
NOTE
}

\section{Association of egg traits and feathering mutants in domestic fowl}

\author{
R.D. CRAWFORD \\ Department of Animal and Poultry Science, University of Saskatchewan, \\ Saskatoon, Saskatchewan S7N OWO, Canada
}

\begin{abstract}
Summary
A search was made for association of egg numbers and egg quality traits with genes for frizzling $(F)$, muffs and beard $(\mathrm{Mb})$, and their normal alleles in domestic fowl. Hens from the fifth, sixth, and seventh generations of a segregating population were each studied for two months late in their first production year. Egg numbers, weight, shell thickness, albumen quality, and incidence of blood spots and meat spots were compared. Hens with muffs and beard produced eggs with thin shells $(P<.01)$ compared to hens with the wild-type allele. There were no major effects of feathering loci on other egg characteristics examined.
\end{abstract}

Key words : feathering mutants, egg traits, domestic fowl, pleiotropic effects.

\section{Résumé}

Relations entre caractéristiques des œufs et mutants du plumage chez la poule domestique

Cette recherche vise à préciser les relations existant entre, d'une part, la quantité et la qualité des œufs et, d'autre part, les gènes $F$ (plumage frisé), $M b$ (favoris et barbe) et leurs allèles normaux chez la poule domestique. Pour ce faire, on a observé pendant 2 mois (vers la fin de leur première année de production) des poules issues des $5^{\mathrm{e}}, 6^{\mathrm{e}}$ et $7^{\mathrm{e}}$ générations d'une population en ségrégation. Les comparaisons ont porté sur la quantité et le poids des œufs, l'épaisseur de la coquille, celle de l'albumen ainsi que la fréquence des taches de sang et de viande. Les poules présentant de la barbe et des favoris ont produit des œufs à coquille plus mince $(\mathrm{P}<0,01)$ comparée à celle des poules de phénotype sauvage.

Aucun autre effet des gènes du plumage n'a pu être mis en évidence sur les autres caractéristiques des œufs.

Mots clés : mutants du plumage, caractéristiques des aufs, poule domestique, effets pléiotropiques.

\section{Introduction}

Associations between qualitative and quantitative traits are usually explained by pleiotropy, linkage, and chance effects. Of the three, association due to pleiotropic effects is of most potential value in commercial production. But distinction between pleiotropy and 
other causes of association is not always easy. Chance effects should not persist if observations are made over several generations of a population or on several different populations. Linkage effects would be expected to dissipate over several generations, and associations of the same degree or kind would not be anticipated in unrelated stocks. Pleiotropy would be indicated when associations continue through many generations and where the same associations occur in diverse populations.

During reproduction of a stock segregating for frizzle, muffs and beard, and the normal alleles of these two mutants, casual observation indicated that frizzle hens were producing larger eggs than their non-frizzle flockmates. Because of the potential value of this association. the present study was undertaken to seek verification and to identify its cause.

A concise account of the two feathering mutants, frizzling $(F)$ and muffs and beard (Mb), has been given by HUTT (1949). Both genes are incompletely dominant autosomal. Frizzling is associated with modifications of metabolism and size of body organs, probably in compensation for poor insulation by the feather coat. No mention has been found in the literature of association between frizzling and egg quality traits. HUTT (1964) reported that sexual maturity was delayed in $M b$ pullets, and MERAT (1962) observed a reduction in wattle size in the presence of $M b$. In a large study of association between qualitative and quantitative traits, Lowe et al. (1965) found that birds with muffs and beard had lower adult body weight, and egg weight at 32 weeks of age was reduced by 1.1 grams; they found no association of muffs and beard with age at maturity, egg production, albumen quality, shell thickness, egg shape index, or egg weight at 55 weeks of age.

\section{Materials and methods}

The population under study originated from a bantam male, exhibiting frizzled feathers and muffs and beard, mated to normal Brown Leghorn females. Their progeny were mated inter se to establish a segregating closed flock. In each generation, flock mating combinations were planned to ensure a 1:1:1:1 ratio of genotypes resulting from presence of the two feathering mutants and their normal alleles (Table 1). Birds of the fifth, sixth and seventh generations were used in the present study.

In the first year, six hens of each of four genotypes (Table 1) were studied for 52 days beginning when they were twelve months of age. They were individually caged. Egg numbers were recorded daily and all collectable eggs were measured to determine weight, specific gravity, Haugh units, and incidence of blood spots and meat spots. The study was repeated a year later on the next (sixth) generation beginning with twelve hens per genotype ; there was some mortality during the 60-day trial and data are reported only for the survivors. An identical procedure was followed in a 60-day trial with the seventh generation. Data were analyzed by analysis of variance (STEEL and TORRIE, 1960).

\section{Results and discussion}

Egg production data, expressed as total eggs laid per hen during the trial, are shown in Table 1 and analysis in Table 2. Production was measured during May and June of each year when environmental temperatures were rapidly increasing and when the birds were nearing the end of their laying cycle. There were no significant differences among genotypes 
nor was any one genotype consistently superior to the others. There were highly significant differences among generations reflecting uncontrolled environmental effects. There were also highly significant interactions between generations and each of the feathering loci under study; these are of doubtful biological importance and probably reflect chance events.

This study had been prompted by the observation that frizzle hens of Generation 5 were laying larger eggs than their wild-type flockmates. Formal measurement indicated that this was indeed the situation (Table 1). However, similar effects were not evident in data for Generations 6 and 7, and statistical analysis (Table 2) did not reveal any significant differences. Lowe et al. (1965) had found no relation between $M b$ and egg weight at 55 weeks of age, which is consistent with the present findings. They had, however, found that egg weight at 32 weeks of age was reduced by 1.1 grams. It is tempting to explain this by the delay in sexual maturity in $M b$ pullets reported by HUTT (1964) but a significant delay is not evident in the analyses of Lowe et al. (1965). Observations at a comparable age were not made in the present study. It would appear valid to conclude that weight of eggs from adult birds is not affected pleiotropically by the frizzling or muffs and beard loci.

Egg shell thickness was evaluated by measuring specific gravity of intact eggs. Hens carrying the muffs and beard gene produced eggs with thin shells $(P<.01)$ (Table 2). It would be of interest to obtain further data since the observed differences (Table 1) are very small, and to examine hens which were homozygous $M b M b$ to determine whether a dosage effect exists. Lowe et al. (1965) had found no association between the muffs and beard trait and egg specific gravity.

Albumen quality, as measured by Haugh units, was not affected by alleles at the two feathering loci under study. However, statistical analysis revealed a significant interaction between the two loci (Table 2). Interpretation of this interaction is not certain, but it may be an artifact of the very large generation effects $(P<.01)$ that were encountered. LowE et al. (1965) found no association between albumen quality and the muffs and beard locus.

Inclusion bodies present technical difficulties in measurement. In this study they were recorded as present or absent, and within a generation all observations were made by the same person. There were generation differences in blood spot incidence, which may reflect differences among observers, but otherwise relationships were negligible.

In a population segregating for many generations, such as the one under study, it would be expected that linkage associations established in the first cross would diminish with succeeding generations. There is no indication that linkage explains the associations observed here. Although of low magnitude, the association of the muffs and beard locus with shell thickness was consistent across generations which is indicative of pleiotropy. Further data are needed to verify a pleiotropic relationship. Since the present data were derived from a comparison of mutant heterozygote with homozygous wild-type, it would be very helpful to include mutant homozygotes in future studies to determine whether a dosage effect exists.

Received December 2, 1982. Accepted January 10, 1983. 


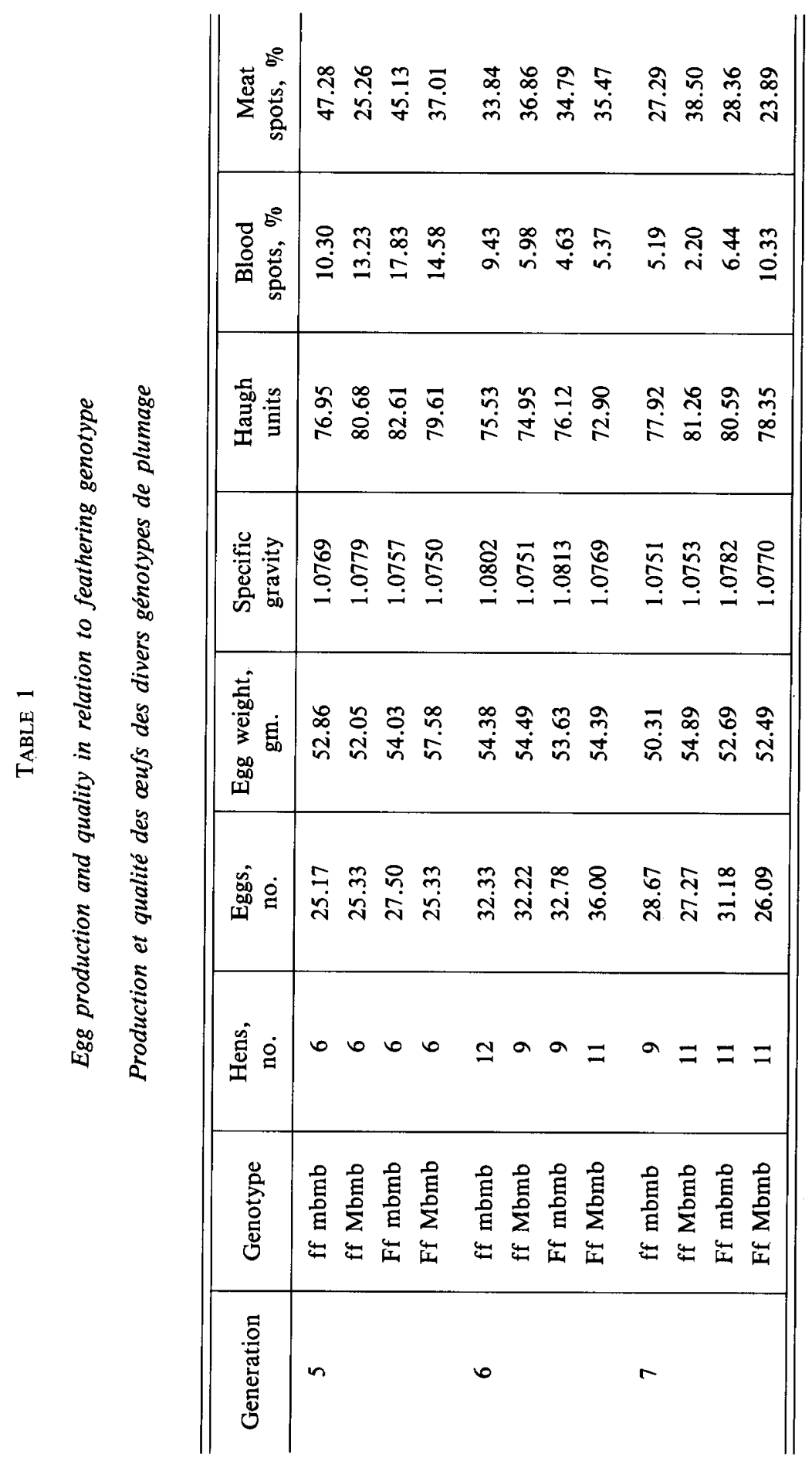




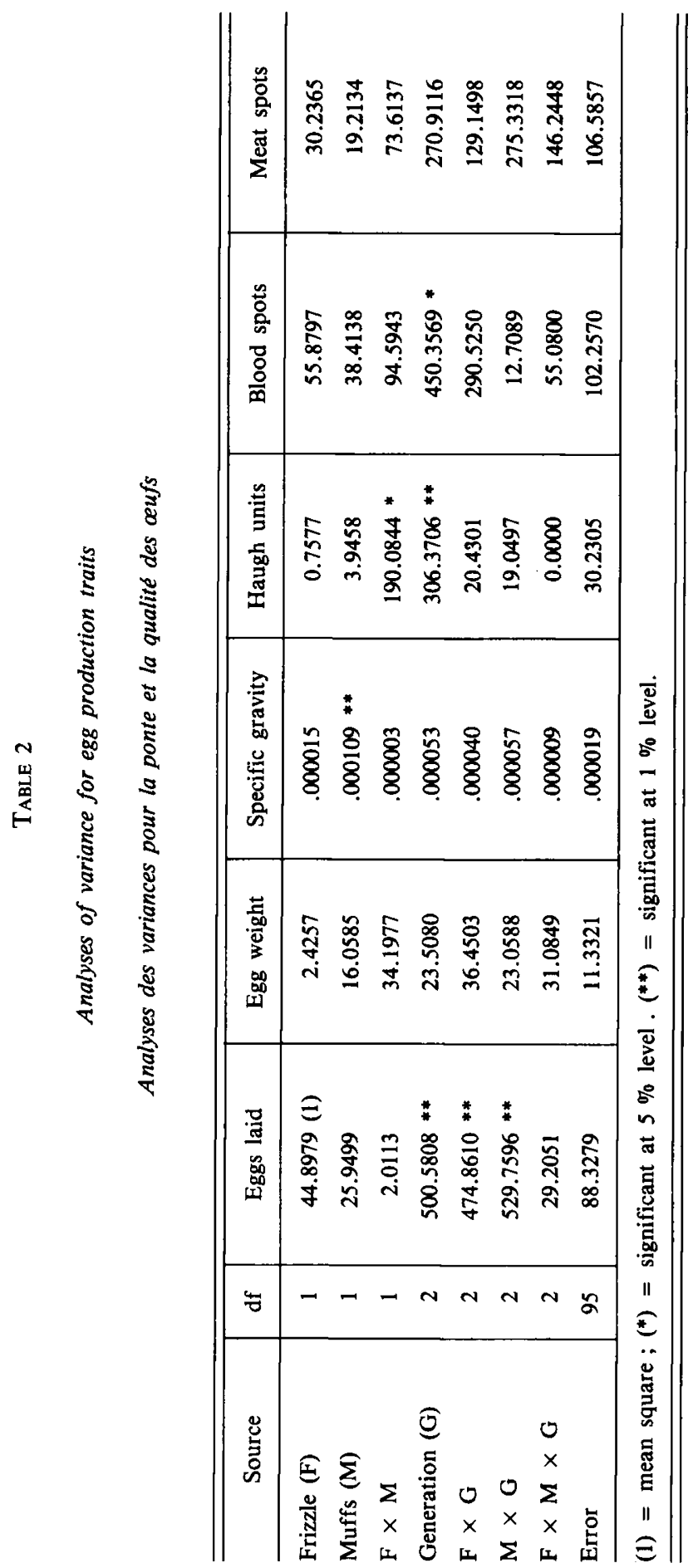




\section{Acknowledgements}

Student research assistance by K.S. LitTle, G. Steranko, A.J. Morrow, and F.E. Robinson is acknowledged with thanks. Assistance with statistical analysis was provided by Dr. D.E. BERNON, postdoctoral fellow. Financial support was provided by Saskatchewan Agricultural Research Foundation and by Agriculture Canada.

\section{References}

HuTt F.B., 1949. Genetics of the fowl. McGraw-Hill Book Co., Inc., New York.

HUTT F.B., 1964. A quest for linkage and pleiotropic effects of 8 loci that determine breed characteristics in the fowl. Poult. Sci., 43, 1332 Abstract.

Lowe P.C., WILSON S.P., HARrington R.B., 1965. Association of some qualitative and quantitative traits in chickens. Poult. Sci., 44, 106-112.

Merat P., 1962. Existence d'un gène « majeur » influant sur la taille des barbillons chez la poule. Ann. Zootech., 11, 157-158.

Steel R.G.D., TORRIE J.H., 1960. Principles and procedures of statistics. McGraw-Hill Book Co. Inc., New York. 